\title{
PEDOMAN PENULISAN NASKAH
}

Naskah yang dimuat adalah hasil penelitian atau konsep pemikiran dalam bidang ilmu tanah dan keairan yang belum pernah diterbitkan atau tidak sedang dalam penyuntingan di publikasi lainnya.

Naskah ditulis dalam bahasa Indonesia atau bahasa Inggris, diketik menggunakan pengolah kata MS Word dengan layout ukuran kertas kwarto dengan margin $3 \mathrm{~cm}$, spasi 2, Times New Roman 12. Jumlah halaman keseluruhan termasuk table dan ilustrasi maksimal 20 halaman termasuk gambar dan tabel, disusun sebagai berikut:

\section{Halaman Sampul}

Judul, Nama Penulis, Alamat lengkap, Instansi Penulis beserta no.telp/fax dan e-mail penulis (bila ada), tanggal pengiriman naskah.

\section{Halaman Isi}

JUDUL (maksimal 14 kata); ABSTRAK (dalam bahasa inggris dan Indonesia, 1 paragraf 1 spasi, font 11,maks. 300 kata) yang secara lengkap memaparkan tujuan, metode, hasil penelitian dan kesimpulan dengan kata kunci; secara alfabetis: (tidak lebih dari 5 istilah); PENDAHULUAN; BAHAN DAN METODE; HASIL DAN PEMBAHASAN; KESIMPULAN; DAFTAR PUSTAKA (disarankan lebih dari 80\% acuan dari jurnal terbitan 10 tahun terakhir). Judul BAB ditulis di tengah, kapital, cetak tebal, tanpa nomor. Judul Sub Bab ditulis di margin kin, kapital pada awal kata, tanpa nomor. Penulisan simbol matematik, unsur kimia, satuam metrik menggunakan standar Sistem Internasional. Istilah asing atau nama ilmiah dicetak miring.

Contoh penulisan sumber kutipan/pengacuan di dalam naskah:

.... Bailey (1993) menyatakan bahwa....

.... sesuai dengan jenis lempung dalam batuan karbonat (White, 1988; Mulyanto,2006).

Contoh penulisan daftar pustaka:

\section{Jurnal}

Prendergast, JB. 1995. Soil Water Bypass and Solute Transport Under Irrigated Pasture. Soil Sci. Soc. Am. J. 59:1531-1539.

\section{Skripsi/Tesis/Disertasi}

Nursyamsi D. 2008. Pelepasan kalium terfiksasi dengan penambahan asam oksalat dan kation untuk meningkatkan kalium tersedia bagi tanaman pada tanah-tanah yang didominasi mineral liat smektit. [Disertasi]. Institut Pertanian Bogor, Bogor. (in Indonesian).

\section{Buku}

White, W. B. 1988. Geomorphology and Hidrology of Karst Terrains. Oxford University Press.

\section{Bab dalam buku}

Bailey, SW. 1993. Review of the Structural Relationship of the Kaolin Minerals. In: Murray H, Bundy W, Harvey C(editor). Kaolin Genesis and Utilization. Boulder, CO: The Clay Mineral Society.p 5-42.

\section{Prosiding}

Wagg, C., Bender, S. F., Widmer, F., \& Van der Heijden, M. G. A. (2014). Soil biodiversity and soil community composition determine ecosystem multifunctionality. Proceedings of the National Academy of Sciences of the United States of America, 111(14), 55-60. https://doi. org/10.1073/pnas.1320054111.

\section{Informasi dari Internet}

Foster, J., D.J. Chittleborough, and K. barovich.2006. Genesis of Terra Rossa over Marble and the Influence of a Neighbouring Texture Contrast Soil at Delamere, South Australia.

http://www.regional.org.au/asssi/Foster,J/Left permission.doc. [12 Mei 2006]

\section{Tabel dan Ilustrasi}

Tabel disajikan terbuka, tanpa kolom, menggunakan program MS Word atau MS Excel. Ilustrasi dijital disarankan menggunakan format JPG, hitam putih. Ilustrasi berupa foto dicetak pada kertas mengkilap, hitam putih. 


\section{Daftar Isi}

6. Beberapa Sifat Fisika dan Kimia Tanah pada Areal Revegetasi Tanaman Sengon di Waste Dump Tambang Batubara Kalimantan Selatan

(Soil Physical and Chemical Properties Study in Revegetation Area of Sengon in Waste Dump South Kalimantan)

Dwi Ayu Fitrianti, M. Nurcholis, dan Djoko Mulyanto

7. Analisis Indeks Kualitas Tanah Lahan Kering pada Berbagai $61-72$ Penggunaan Lahan di Desa Ngalang, Kecamatan Gedangsari, Kabupaten Gunungkidul

(Analysis of Dryland Soil Quality Index in Various Land Uses in Ngalang Village, Gedangsari Subdistrict, Gunungkidul District) Arya Satrya Wicaksono, Susila Herlambang, dan Didi Saidi

8. Kajian Sifat Fisika Ultisol pada Lahan Budidaya Nenas dengan $73-82$ Berbagai Pola Rotasi di PT. Great Giant Pineapple Terbanggi Besar, Lampung

(Study of The Physical Properties of Ultisols on Pineapple Cultivation Land with Various Rotation Pattern at PT Great Giant Pineapple Terbanggi Besar, Lampung) Angga Suseno, AZ Purwono Budi Santoso, dan Susila Herlambang

9. Potensi Kompos Tandan Kosong Kelapa Sawit terhadap Ketersediaan Fosfor Podsolik Merah Kuning dan Serapannya oleh Bibit Kelapa Sawit (Elaeis Guineensis Jacq.)

(Potency of Oil Palm Bunches Compost for Available P Supply on Red Yellow Podsolic and Phosphorus Uptake by Palm Oil (Elaeis guineensis Jacq.) Seedlings)

Ulinnuha Difana Putri, Lelanti Peniwiratri Dan R. Agus Widodo

10. Uji Aktivitas Dekomposisi dari Beberapa Inokulum Komersial pada Beragai Jenis Bahan Berdasarkan Jumlah $\mathrm{CO}_{2}$ yang Terbentuk

(Decomposition Activities Test of Some Commercial Inoculums on Various Types of Materials Based on The Generated Amount of $\mathrm{CO}_{2}$ ) Yanisworo WR, Dessy Apriyani Sohilait, , dan R. Agus Widodo 